\title{
Feminist Graphic Narratives: The Ongoing Game of Eluding Censorship
}

\author{
Dr. Emira Derbel \\ University of Manouba, Tunisia \\ Buraimi University College, Oman
}

Doi: $10.2478 / \mathrm{mjss}-2019-0005$

\begin{abstract}
Censorship today has been acquainted with the action of silencing, suppressing or even making unheard and unseen what is considered as culturally and socially unacceptable. Its omnipresent and widespread aspect made the concept touches upon all literary genres among which graphic narratives by women prove to be censorship's target. The medium's multimodality and ability to explore culturally, socially and religiously troubling spaces has categorized feminist graphic narratives as "soft weapons" endowed with a stylistic capacity and a system of grammar to subvert and to resist control. It is in this context that that this paper procures a theoretical definition of censorship by linking it history to that of comics and graphic narratives in order to shed light on the historical ties informing today's conflictual relation between censorship and feminist graphic narratives. By taking the example of Marjane Satrapi's Persepolis and Linda Barry's One! Hundred! Demons!, the study stresses the capacity of graphic narratives to elude the gaze of the censor through the adaptation of different evasive techniques.
\end{abstract}

Keywords: Feminist graphic narratives, censorship, control, elude, counter-censorship

\section{Introduction}

The act of excluding, blurring, oppressing or silencing an expression, a thought, an image has for long been a process realized through the interconnectedness of censorious systems or agents responsible for regulating or suppressing an entity, ideas, visual or literary production. Censorship has for long been literature's contesting rival. Jansen (1991) describes censorship as "the knot that binds power and knowledge", and this complex and concurrent relationship between literary knowledge and mechanisms of suppression has determined today's conflictual relation between censorship and literature in general and graphic novels in particular (p. 221).

In its modern embodiment, censorship grows contemporaneous with visual forms of literacy such as comics and graphic novels for the amalgamation between picture and narrative text launches a double ethical heaviness on the term. The process then ironically categorizes itself as the savior of society and the protector of students and teens innocently seduced by pictures (Mhamdi, 2017b). As graphic novels gained their emplacement in public and private libraries, the potential for censorship attempts increased. The more graphic novels map their presence in college's curriculum, the more censorious voices rise to stop their inclusion into educational systems.

In order to disturb and to obfuscate the teaching or circulation of graphic novels, censorship takes multiple forms of suppression dating back to the Comic Code authority established by the comic book industry itself in 1954 (Tbachnick 2017, p. 31). Therefore, comic books were not released without a seal of approval indicating their moral acceptance and thus their social eligibility. Regulation of the medium and its suppression encompasses the banning of graphic books, a ban that yearly decorates the web pages indicating which titles are allowed to circulate in libraries or 
tolerated being included in class curricula and other titles banned from circulation. Ironically enough such process gave rise to underground comix, comic books that circulate outside the confines of the Comics Code using their art to abjure authority. Henceforth, censorship is not merely a matter of process "reduced to a circumscribed and predefined set of institutions, but is produced within an array of constantly shifting discourses, practices and apparatuses.[Censorship] is an ongoing process embodying complex and often contradictory relations of power (Khun, 1988, p. 127). Once suppressed a counter movement flourishes to challenge and to escape suppression.

As a result, censorship acquired multiple and shifting definitions. This research paper dwells on the traditional models of censorship and it outlines the contemporary theoretical consideration of the term that proved to be more inclusive of today's debate between censorship and graphic novels. The paper sheds light on the existence of tight relationship between socio-historical contexts and censorship as a mode of control and silencing rather than mere action of prohibition. Bearing in mind "that each literary work cannot stand by itself since it's always already a response, an illustration, or a representation of a particular historical or socio-political context" (Derbel, 2017b, p. 39), this paper also demonstrates the various modes of resistance or the counter-censorship discourse that graphic novels have adapted to elude the gaze of the socio-politico-historical censor.

\section{Censorship: Towards a Theoretical Definition of the Concept}

Traditional understanding of censorship acknowledges that the concept implies the silencing of a resistant subject speech, an action led by a single censorious agent or authority, "an absolute choice between prohibition and freedom" (Kuhn, 1988, p. 4). The traditional hypothesis based on the 'either/or' duality has been declined by critics such as Judith Butler, Michael Holquist, Annette Khun and Richard Burt, who have instead advocated the omnipresence of censorship (Freshwater, 2004 , p. 1). Holoquist (1994) criticizes the allusion of freedom by which censorship is endowed, he states, "to be for or against censorship is to assume a freedom no one has" (p. 16). His main argument centered on the claim that censorship is "pervasive and insistent in all disciplines that mediate language, an act of repressive intervention", it is omnipresent and inescapable (1994, p. 17).

Similarly, Annette Khun (1988) defined censorship as "an ongoing process embodying complex and often contradictory relations of power" (p. 127). Therefore, censorship is approached as constitutive rather than regulative. A process that recalls Pierre Bourdieu's concept of "market" that does not only accommodate linguistic expression, but also behavior is "ephemized" transformed into self-ensorship through the process of anticipation (1982, p. 20). Censorship, therefore, is strictly connected to the social, cultural and historical context. Hence, censorship is "more than one thing, [it] occurs at more than one place and at more than one time" (Burt, 1998, p. 18 ). It is the product of multiple forces.

Contemporary definitions of censorship foreground its dispersed and disseminating character. It is in this context that the conceptualization of constitutive censorship is deeply rooted and informed by the work of Michel Foucault. Censorship operates at the level of discourse and institutions (Foucault, 1980, p. 199). Control and surveillance reside at the heart of the Panoptic society that represses and controls individuals casting them into a binary division (Foucault, 1977, p. 199). Hence, Censorship is an omnipresent necessity, an idea elaborated by Bourdieu (1991) when he posits that censorship determines both linguistic content and form directed by "known forms and recognized norms" (p. 139). Additionally, Althusser (1971) bends the simplistic definition or perception of censorship as the imposition of state repression and stresses the role of ideological state institution in the preservation of ideology.

Althusser's interpretation of censorship transcends its traditional understanding as merely imposed by an authority on individuals. Similarly to Foucault, Althusser goes beyond the simplistic vision of censorship as a "negative instance of repression", it is, instead, "considered as a productive network which runs through the whole social body" (Foucault, 1980, p. 199). Bourdieu (1991) further elaborates on censorship as the product of the subject's internalization of "forms of perception and expressions" which become even habitual (p. 37). Thus, censorship becomes a structural necessity haunting daily modes of expression that governs the individual's need for 
socialization. Power is internalized and censorship is its ultimate pinnacle.

Likewise, censorship is not only constitutive or regulatory, but also productive as it directs individuals and governs their speech. Following the same line of thought, Judith Butler (1997) posits:

Censorship is most often referred to as that which is directed against persons or against the content of their speech. If censorship, however, is a way of producing speech constraining in advance what will not become acceptable speech, then it cannot be understood exclusively in terms of juridical power (p. 128).

Butler, therefore, does not conceive censorship in its traditional view as being imposed by the state or by an authority on less powerful people, but perceives it as "productive and formative power" (1997, p. 133). By distinguishing between 'implicit' and 'explicit' forms of censorship Butler examines the theory of psychoanalysis to figure out that primary forms of repression are responsible for the formation of the subject (1997, pp.137-138). An idea that further illustrates the role psychoanalysis has played in the theorization of censorship.

The idea of censorship as internalized and linguistically omnipresent is foundational to the theory of psychoanalysis. The human psyche functions as a repressive mechanism of troubling or prohibited thoughts and experiences. Censorship, therefore, is generated from within. Such conceptualization of the concept is firmly engraved in the work of Sigmund Freud who clarifies that censorship takes place at an early stage of the human being's life, it resides in the continuous conflict between our "repressed" "unconscious" and "conscious" ( as cited in Gay, 1995, p. 569). Such "implicit" process of censorship operates even "on a level prior to speech", as a primary form of repression "that is not performed by a subject but, rather, whose operation makes possible the formation of the subject" (Butler, 1997, pp. 137-138). The subject's attempt to bring the repressed into the surface or into the patient's consciousness provokes according to Freud a "resistance" then censorship is performed (as cited in Gay, 1995).

Censorship, then, exists in a "continuum", it is an endless process of suppression, exclusion, selection and regulation (Butler, 1998, p. 248). Such disciplinary power negates the possibility of subversion which denies individual's accessibility to free speech and free expression, a disquieting conclusion as it negates any faith in the possibility of escaping the grips of the censor. Literature, however, has witnessed the rise of hybrid literary genres that have challenged censorious interventions. Since "censoring a text is necessarily incomplete", because "something about the text under censorship exceeds the reach of the censor", comics and graphic novels inherited an internal dynamism at both visual and textual levels that has for long disturbed, challenged and resisted censorious voices (Butler, 1997, p. 129).

Comics and graphic novels are hybrid genres which embody stylistic innovations and strategies capable of resisting or even eluding censorious powers. Despite censors' omnipresent desire "to fix meaning, expunge ambiguity and to fill the vacuum into which interpretation rushes", graphic novels escape the unification or the fixation of meaning due to its visual dimension that lies bare the status quo dearly maintained by existent regimes (Freshwater, 2004, p. 235). Furthermore, graphic novels adapt a varied set of icons, visual allusions, symbolism and a system of grammar that inherits the genre its dialectic and active aspect boosted by the dynamic involvement of the reader in the process of interpretation (Al-Mohammadi, 2014; Al-Mohammadi \& Derbel, 2014; Derbel, 2017a). Writers of graphic novels have challenged moments of silence generated by the repressive aspect of censorship amidst tumultuous censorious voices.

A graphic narrative as chute defines it "is a book-length work in the medium of comics and the term [also] shifts to accommodate modes other than fiction" (2008, p. 453). The term encompasses a wide array of literary modes such as autobiography arguably the most dominant one. Also termed by Gillian Whitlock (2006) as "autographics" for their amalgamation of narrative text and images, an aspect that has made the genre a privileged medium for conveying taboos and for representing prohibited social and political spaces (Mhamdi, 2017a). This paper tackles the long history of censorship committed against comics and graphic novels in particular and it also sheds light on the challenging capacity of the medium to subvert and to resist censorship by eluding its ties due to the genre hybrid aspects. In this context, the paper dwells on the exploration of the disturbing echoes that graphic narratives by women writers such as Marjane Satrapi's Persepolis and Linda Barry's One Hundred Demons have left on Western and Eastern socio-political scenes. 


\section{Graphic Narratives: A History of Censorship}

The comic industry in the United States has for long been caught into an increasing tide of criticism that has unsettled the reception of the medium and has marked its fluctuation between censorship and liberty. According to Boichel (1991), the period from 1938 to early 1950s marked the rise and spread of comics as the mostly read books ever among American children and teens (p. 69). The "Golden Age of Comics" was mostly characterized by the flourishing of the superhero figure that grew popular during the second World War when the industry was driven by the zeal of winning the war through the creation of cartoon soldiers such as Batman and Captain America by writers like Will Eisner, Jerry Robinson and Stan Lee (Irving \& Kushner, 2012, p. 45).

Comics then supported a national mission and nourished the American nation's sense of pride and patriotism. No sooner, comics began to trace their trajectory in the history of American art that they witnessed censoring moves and an outburst of campaigns seeking to demolish their seemingly innocent dimension as Frederic Wertham fiercely claimed in The Seduction of the Innocent (1954). A rabid transition from a heroic frame to an emphasis on obscenity and vulgarity had fueled the comments of comics proponents during the 1950s. Wertham (1954) drew on the fake evasive veracity of what he terms 'picture reading' that is able to attract illiterate minds to "particularly violent or socially intriguing ideas" (p. 18). Additionally, the abstract dimension of comics allowed, according to Irwin Howe, Children to sink into an "abstract schematization of violence and sadism" (1948, p. 122). Hence, the visual dimension stimulates a multi-layered message that might involve the child for instance in criminal or erotic activities. This power of the visual representation is also echoed in the works of Mhamdi (2016; 2017c and 2017d) emphasizing the strong impact of the visual medium on channeling public opinions and creating certain frames of others.

Such crusade led to the development of the Comic Code Authority in 1954 or what has been termed as the Comics Code "Seal of Approval" that has to appear on the cover of each comic book as a sign of moral acceptability before being ready for circulation. First signs of censorship hit harshly an industry supposed to be our children's favorite pastime. Though in comics, as McCloud (1994) contends in Understanding Comics, "words and pictures are like partners in a dance and each one takes turn leading", harsh criticism during the 1950s was solely directed against the visual dimension as it was considered a filter of obscene images, violence and vulgarity (p. 156). Therefore, phrases such as "entrapping American's children", "violating innocent minds" or even the "marijuana of the nursery" invaded the American social scene (1998, p. 15). Consequently, many terms related to the lexical paradigm of horror and terror were banned from the comic books titles.

Established by the cartoonist Harvey Kurtzman in 1952, Mad Comics: Humor in a Jugular Vein, later Mad magazine, initiated the project of comics as a critique of American media. Mad was, likewise, an inspiration for underground comix, the first spark of oppositionality to the censorious aspect of the code. Silver Age or the post-code period witnessed the surge of what has been known as the "Underground Comix Revolution in between the 1960s and 1970s" (Hatfield, 2005, p. ix). Such countercultural comix movement exhibited a wild, liberating, radical and innovative means of artistic creation that "while still constrained by the Comics Code of 1954, [comics] changed substantially in response to the political climate of the time" (Booker, 2014, p. xxvi). The Underground Comix of the 1960s were a form of subculture comix characterized by their irreverence toward authority, cultural values and their depiction of social taboos. Sabin (2001) comments on the strategy of the underground comics movement: "[If] the Comics Code meant, essentially, that a comic was prevented from saying anything meaningful about the real world, then by defying it this possibility was reawakened (p. 92). Underground Comix challenged and resisted both explicit and implicit forms of censorship.

Amidst governmental censorship, underground comix "were an influential cultural vehicle, challenging and arresting because it mediated on the violation of taboos", yet its circulation remained limited (Chute, 2008, p. 465). A number of prohibited from circulation magazines took the burden of self-publishing without being limited to commercial strictures. This alternative subculture revolutionized the comic industry and injected on its vein a sense of defiance. The growth of the underground Comix paved the way towards many American women cartoonist to construct a space from which they were able to sprout political concerns. As Chute stresses in her introduction to 
Graphic Women: Life Narrative and Contemporary Comics, "It is only in the comics underground that the US first saw any substantial work by women allowed to explore their own artistic impulses" (2010, p. 20).

Despite its collapse in the 1980s, the underground "changed the face of what we consider 'literature' and gave us the risk-taking self-representation we see in today's graphic narratives by women" (Chute, 2010, p. 26). Out of the womb of the underground, today's most daring graphic narratives have proved that comics is an elevated literary form and not a mere juvenile medium. Graphic narratives of the decade function as an eye witness to political upheaval, socially forbidden spaces and traumatic life events through which the self and body, mainly the female one, could not break free unless graphically unveiled.

Today's graphic narratives are endowed by a therapeutic dimension that offers freer platforms for many graphic women illustrators and writers to picture what is often placed outside of public discourse despite the persistent chase of the censor. Feminist graphic narratives, chief among them graphic memoirs, inherited the thorny and edgy aspect of their precursors, not for the sake of literary propaganda as much as it is a new form of self-representation that derails from traditional narrative in its capacity to produce immediacy and poignancy on the reader/viewer to give voice, presence and visibility to its women (Derbel, 2017a). Though vision in the context of comics representation of women, as Donna Haraway advocates in "The Persistence of Vision", is "a maligned sensory system in feminist discourse", it remains highly threatening, demeaning in some social contexts, in short 'malignant weapons' in need for extinction (1997, p. 283).

Graphic narratives by women, particularly, graphic memoirs as Marjane Satrapi's Persepolis (1) and (2) and Linda Barry's One! Hundred! Demons! have been targets of censorship via implicit and explicit modes whether by banning their circulation from libraries, their teaching in schools or by propagating in society or in media a negative representation of the work. These various modes of censorship did not bend or diminish the success of these three graphic narratives worldwide. In fact, such graphic memoirs visited troubled spaces and have been posited as dangerous and even followed judiciary and put on trial. Yet, the capacity of graphic narratives to defy censorship due to its various elements and techniques owned the medium a challenging and subverting aspect.

\section{The Production of a Counter-censorship Discourse in Feminist Graphic Narratives}

Graphic narratives such as memoirs are hybrid genres by excellence for they are composed of a visual and a narrative dimension. Both parts are complimentary and frame the connotative dimension supported by a grammar of comics that further supports the medium's expressive potential. Graphic narratives largely surpass traditional narratives due to their ability to convey sound, through the frame's shape for instance, and emotions through the visualization of actions and of facial expressions. Thus, comics proved to be a challenging, and directly intervening in social and political arenas. It is in this context that Leigh Gilmore contends that "graphic memoirs open up new and troubled spaces" (1994, p. 70).

In Reading Autobiography, Sidonie Smith and Julia Watson comment that "graphic memoirs have become a site for telling complex stories of gender, sexuality, trauma and the nation" (2010, p. 168). In fact, the medium's "cross-discursive form", that dangerous amalgam between the verbal and the visual dimension impinges on the reader "to observe stories that are not explicitly signaled by the verbal plane" (Smith \& Watson, 2010, p. 169). Hence, the medium denudes its message and even loads it with multiple layers of meaning that made the decoding of its message a controversial issue. Such polymorphous aspect of the graphic narrative, its ability to transmit multiple interpretations constitute forms of distortions, once detected by readers, they function as "strategies of dissimulation [that] dismantle the threat of silencing" (Levine, 1995, p. 2).

Freshwater (2004) posits that, "Repression is not a single event, but a series of acts that demand a constant expenditure of force" (p. 231). Following the same line of thought, Satrapi's Persepolis figures as one of the graphic memoirs that made use of the visual medium to condemn the Islamic Republic's recurrent trials to censor individual freedom by utilizing systems of surveillance and of political and religious oppression. Satrapi's graphic memoir is an act of witnessing historical trauma, an artistic mode of representation that recalibrates the Western 
readers understanding of Iranian culture. Fighting censorship and restrictions is one of the main themes of Satrapi's graphic memoir. The various scenes of tortures, mass public violence and enforced veiling in Persepolis are reminiscent of the writer's main aim to state that any form of totalitarianism and extremism can only yield a handicapped society. Ironically enough, upon its release, the graphic memoir did not only witness a phenomenal success, but also controversial views as whether or not teachers should teach Persepolis in the United States of America. Unfortunately, Persepolis fails prey to the curse of censorship.

Satrapi's Persepolis, for instance, is a comic book that has elevated the status of the medium in its way of representing the history of Iran and the struggle of the writer's avatar, Marjane, not to succumb into passivity and subservience under a new Islamic government during the pre and post Iranian revolution. Satrapi's graphic novel offers to its reader multiple worlds: that of the writer, the avatar Marji, the adolescent and the grown woman in Persepolis (2), a characteristic by which the memoir is blessed and a curse by which the censor is loaded. This multiplicity of stories supported by the visual dimension produces a proliferation of interpretations that pose problems for a system of censorship haunted, as Holoquist puts it, by "the monologic terror of indeterminacy" (1994, p. 22).

Through her plain black and white panels, Satrapi sought to dismantle the monolithic image attributed to Muslim women by advocating a new model of Iranian womanhood. In her introduction to Persepolis, Satrapi reveals her main aim behind writing her graphic memoir when she clarifies that "[...] An entire nation should not be judged by the wrongdoings of a few extremists" $(2008, p$. $\mathrm{x})$. Persepolis, a memoir in comics, that triggers "a humanizing frame of reference" through its universal drawing of the child Marji in Persepolis (1), the suffering of Iranian women and the fight for liberty of thought and being as opposed to a theological censorship driven by a post-revolutionary totalitarianism (Whitlock, 2006, p. 191).

In "Sex, Violence, and Radical Islam: Why 'Persepolis' Belongs in Public Schools" Noah Berlatsky writes, "the Chicago Public school Board decided on the banning of Persepolis from all curriculums and mandated that the graphic memoir be pulled from all libraries" (2013, n.p). Persepolis has been fiercely contested for placing images of torture and sex thus inclined to disseminate violent or pervert behavior among American kids. The Chicago controversy has brought to the fore the traditional conflict between liberty of thought, freedom of information and educational needs. A huge backlash concomitantly took place in which students protested and Satrapi comments in an interview "Read the book first and don't just be shocked by one picture" (Hill, 2006, p. 10). This act of restriction in the Chicago school is not a solitary one. Persepolis was also put under scrutiny in Iran and it was denounced by the religious leaders of the country.

The Oscar-nominated motion adaptation of Persepolis did not escape censorship. In fact, the Iranian authorities have banned the film and have branded it as "anti-revolutionary" (Berlatsky, 2013, n.p). While the movie has reaped an Oscar for the Best Animated Feature as well as Best Foreign Language Film and the Jury Prize at the 2007 Cannes Film Festival, it unfortunately, harvested anger and disdain in Iran, Lebanon and the United Arab Emirates for offending Islam. Furthermore, the movie has also caused an outburst in the Tunisian social scene after being broadcasted in Nessma TV in 2012. No wonder that many Tunisians have accumulated antagonistic counter reactions and have been left in utter confusion for the country itself was torn by multiple political discourses that have obscured the choices of Tunisians vis a vis the granting of faith or chance to religious Islamic political parties or following their past loyal division between politics and religion. Meanwhile, the movie touched upon such indecision when it denounces the fear and restrictions that individuals may face under a totalitarian theological regime.

Censorship of graphic narratives or memoirs in the Iranian context brings back a remote tradition of suppressing or oppressing self-narratives by Iranian women writers in Iranian society. Oppression, at this level, is both intellectual and cultural. In Veils and Words, Farzanah Milani further brings this argument to the fore when she asserts that "the norms and values that regulated [Iranian] women's physical concealment applied equally to their literary expressions" (1992, p. 46). For centuries literary writing and intellectual expression were confined within the family space. By prodding women's literary existence to the edge of invisibility, Iranian society has for long sealed the pact of censorship. Persepolis, however, signals an act of subversion, a way of writing back to a 
social censor.

The representation of sexual violence committed against children, young girls or adolescents routinely raises questions of censorship. Linda Barry's One! Hundred Demons! is an 'autobiofictionalography' as Barry herself terms it, a semi-autobiographical graphic narrative that negotiates through its double dimensions "private trauma in public, popular culture formats using aesthetic process of reworking childhood events and emphasizing, in each case, a shared community formed from private pain and taboo knowledge" (Tolmie, 2013, p. ix). The resurrection of trauma in graphic narrative by women serves the victim to overcome her traumatic memory, what Derbel (2014) terms as a "positive nostalgia" offers "ground for change and allows the female identity to overcome traumatic past through the retelling of (her) story" (p. 65). Women's comics art establishes interconnections between gender, race, class, nation and sexuality. Barry's graphic narrative retrieves issues of sexual abuse and incest deemed forms of social taboos culturally censored to challenge trauma and to heal the avatar's psychological entrapment. No wonder Barry's text fails pray to the censor's gaze, disturbed by the capacity of the graphic narrative to analyze the body on the page (Chute \& DeKoven, 2006, p. 769).

The censoring project aligns itself as the protector of innocence usually vulnerable, as J.M.Cotzee (1996) puts it, to "the wiles of vice" mainly channeled, in the case of graphic narratives, through the visual medium (p. 36). The representation of child abuse in Barry's One! Hundred! Demons! has spread public anxiety and parental frustration regarding the dissemination of scenes of child rape. The visualization of nudity and sex abuse furthered social angst about the probable influence of such pictures on children and adolescents. At this level, the reader might have thought about the efficiency of censorship in establishing a censoring wall that dismantles and bends the capacity of comics to outstretch pornography and voyeurism! But, has the reader thought about the techniques and mechanisms adopted by censoring systems to develop a culture of silence, of recasting those child victims to the shadow of fear and shame?

Censoring images or even expressions of child abuse obscures or obfuscates the victim's sense of trauma and supports a culture of shaming and silencing. The victim, then is doubly cast into invisibility. It is in this context that graphic novels as Barry's One! Hundred! Demons! or Satrapi's Persepolis resist "patriarchal projects of erasure" and challenge "a culture of elite that determines what is good taste" (Tolmie, 2013, p. xi). By forcing the reader to see a scene of child abuse, Barry denounces what has been suppressed by taboos for the sake of spreading awareness and transcending trauma by facing it. Therefore, the visual image of abuse becomes "aesthetically and emotionally confrontational, even potentially coercive" (Tolmie, 2013, p. xii). Graphic novels "exceed the reach of the censor", as Butler theorizes, thus censorship is "necessarily an incomplete process" (1997, p. 129). Butler adds that the partiality of censorship is mainly due to the polysemy and dynamism of language (1997, p. 129). In the case of graphic novels, the realm of images is an additional disturbing factor that renders censorship a vulnerable victim.

The immediacy of representation characterizes graphic narratives by women writers. Barry and Satrapi represent trauma in a way that encapsulates the moment free from cultural barriers. "Resilience" is the title attributed to the episode of child abuse in Barry's One! Hundred! Demons! (2002, p. 10). The title itself bears the meaning of transcendence, the victim's capacity to artistically re-imagine trauma indicates a readiness for liberation and emancipation through artistic selfexpression able to elude censorship due to its hybrid character. At this level, art becomes an emancipator act through which both Barry and Satrapi offer an "aesthetic escape" (Tolmie, 2013, p. xiii).

In graphic narratives, memoirs in particular, escape becomes reachable through the construction of the past, time, then, "is represented as space on the page" and the "ça a été ", as I have coined, gains vigor, urgency and immediacy through its illustration in the panel (Chute \& DeKoven 2006; Derbel 2017a). By reconstructing the image of abuse through the act of remembering, the child victim transgresses trauma, sequential art, therefore, turns to be a vehicle for self emancipation. Art is liberating in both senses; on the one hand, it offers the child victim a venue to transcend trauma, on the other hand it allows the artist to elude censorship through the deployment of graphic narratives as the main vehicle of cultural, social and political production.

Richard Burt's understanding of censorship as " a negative form of power" can be partially 
applied or contemplated in the case of feminist graphic narratives (1994, p. xvi). This is mainly due to the hybrid form of the medium which escapes and resists the censor's gaze, on the one side, and due to the medium's ability to denounce or to make visible to a large audience what censorship seeks to repress on the other. Hence, I posit that censorship embodies in itself its own opposite or antagonism, as it ironically exposes what it seeks to repress by falling prey to what I would term, as an extension of Bourdieu's conceptualization of the "habitus", the visual 'habitus' of graphic narratives.

\section{Conclusion}

I would argue that literary censorship is a form of literary terrorism carried out through modes of silencing, repressing or prohibiting the circulation of ideas, opinions and images identified as disturbing or violating social, religious or political taboos. Unfortunately, such forms of constraints are omnipresent, part of a "continuum", a widespread ideology (Butler 1998, p. 241). Despite its pervasive aspect, censorship finds in hybrid texts sites of oppression disturbed by possibilities of transgression.

Feminist graphic narratives bear the capacity to defy censorious acts trapped by the duality of text and image. As opposed to traditional narrative text, the graphic one eludes the censor's gaze and escapes regulatory practices by visualizing what prose narrative remains silent about. In this case, censorship is left with one simple option that of resorting to invisible and silent mechanisms as to stop the circulation of graphic narratives in libraries or as to limit or even denounce their inclusion in school curriculum.

Today overcrowded world of images and social networks has problematized the mission of censorship. Feminist graphic narratives, comics or comic journalism are new versions of previously suppressed narrative forms of the same genres which are gaining tumultuous attention even academically. The body of research carried out on these new forms of media has itself challenged censorship whose mission ironically remains to rework its previous mechanisms of repression in a way to align with the new pace of technology.

\section{References}

Al-Mohammadi, S. (2014). Integrating Reading and Writing in ELT. In R. Al Mahrooqi \& A. Roscoe (Eds.), Focusing on EFL Reading: theory and Practice. (pp. 260-274). New Castle: Cambridge Scholars Publishing.

Al-Mohammadi, S. \& Derbel, E. (2014). To Whom Do We Write?.Audience in EFL Composition Classes. In R. Al-Mahrooqi. V. S. Thakur \& A. Roscoe (Eds.), Methodologies for Effective Writing Instruction in EFL and ESL Classrooms. (pp. 197-207). Hershey, PA: IGI Global.

Althusser, L (1971). "Ideology and Ideological State Apparatuses." Lenin and Philosophy and Other Essays. Brewster. , B (Trans).London: New Left Books

Barry, L (2002). One!Hundred!Demons!. Seatlle: Berkeley, Calif.

Berlatsky, N. (2013, March 19). Sex, Violence, and Radical Islam: Why 'Persepolis' Belongs in Public Schools. The Atlantic. Retrieved August 12, 2018. Theatlantic.com. html

Boichel, B. (1991). The Many Lives of Batman: Critical Approaches to a Superhero and His Media. New York: BFI Publishing.

Booker, K. M. (2014). Comics through Time. A History of Icons, Idols, and Ideas. Santa Barbara, California: Greenwood.

Bourdieu. P. (1991). Language and Symbolic Power. In J.B.Thompson (Ed). (G. Raymon and M. Adamson, Trans). Oxford: Polity. (Original work published 1977).

Burt, R. (1994). The Administration of Aesthetics: Censorship, Political Criticism and the Public Sphere. Minneapolis: $U$ of Minnesota.

Butler, J (1997). Excitable Speech: A Politics of the Performative. London, New York: Routledge.

Butler, J (1998). "Ruled Out": Vocabularies of the Censor." In R.C.Post (Ed.), Censorship and Silencing: Practices of Cultural Regulation. (pp. 247-259). Los Angeles: Getty Research Institute for the History of Art and the Humanities.

Chute, H \& Dekoven, M. (2006). Introduction: Graphic Narrative. Modern Fiction Studies, 52 (4), 767-782.

Chute, H. (2008). "Comics as Literature? Reading Graphic Narrative." PMLA 123.(2), 452-465.

Chute, H. (2010). Graphic Women: Life Narrative and Contemporary Comics. New York: Columbia UP. 
Cotzee, J.M. (1996). Giving Offense: Essays on Censership. Chicago: University of Chicago Press.

Derbel, E. (2017a). Iranian Women in the Memoir: Comparing RLT and Persepolis (1) and (2). UK: Cambridge Scholars Publishing.

Derbel, E. (2017b). The African Novel: The Ongoing Battle against Literary and National Neo-Colonialism. International Journal of Information Technology and Language Studies (1) 1, 39-51.

Derbel, E. (2014). 'Constructing Afro-Caribbean Identity through Memory and Language in Grace Nichols's I Is Along Memoried Woman'. In Selim. Y.F and Mohamed, E (Eds.), Who Defines Me: Negotiating Identity in Language and Literature, pp 63-76. UK: Cambridge Scholars Publishing.

Foucault, M. (1977). Discipline and Punish. (Alan Sheridan, Trans). London, Penguin.

Foucault, M. (1980). Power/knowledge: Selected Interviews and Other Writings. C.G (Ed). (C.G Trans). New York: Pantheon Books.

Freshwater, H. (2004). Towards A Redefinition of Censorship. In B. Muller (Ed.), Critical Studies: Censorship and Cultural Regulation in the Modern Age (pp. 225-246). The Netherlands: Rodopi B V.

Gay, P (1995). The Freud Reader. (Ed). London: Vintage.

Gilmore, L. (1994). Autobiographics: A Feminist Theory of Women's Self-Representation. Ithaca and London: Cornell UP.

Haraway, D. (1997). "The Persistence of Vision". In K. Conby, N. Medina and S.Stanbury (Eds.), Writing on the Body: Female Embodiment and Feminist Theory (pp. 283-295). New York: Columbia UP.

Hatfield, C. (2005). Alternative Comics: An Emerging Literature. Jackson the United State of America: UP of Mississippi.

Hill, Ch. (2006). "Marjane Satrapi Interviewed." International Journal of Comic Art (8)2, 6-33.

Holquist, M. (1994). "Corrupt Originals: The Paradox of Censorship". PML 109.1, 14-25.

Howe, I. (1948). 'Notes On Mass Culture.' Politics 5, 120-123.

Irving, Ch \& Kushner. S. (2012). Leaping Tall Buildings: The Origins of American Comics. Brooklyn, NY: Power House-Books.

Jansen, S.C. (1991). Censorship: The Knot that Binds Power and Knowledge. New York, Oxford: OUP.

Khun, A. (1988). Cinema, Censorship and Sexuality. London, New York: Routledge.

Levine, M. (1995). Writing through Repression. Baltimore: John Hopkins UP.

McCloud, S. (1994). Understanding Comics: The Invisible Art. New York: Harper.

Mhamdi, C. (2016). Transgressing Media Boundaries: News Creation and Dissemination in a Globalized World. Mediterranean Journal of Social Sciences, 7 (5), 272-277.

Mhamdi, C. (2017a). The Use of Political Cartoons during Popular Protests: The Case of the 2011 Tunisia Uprising. Journal of English Studies 15, 193-220.

Mhamdi, C. (2017b). What Can Video Add to the Learning Experience? Challenges and Opportunities. International Journal of Information Technology and language Studies, 1 (1), 17-24.

Mhamdi, C. (2017c). Framing 'the Other' in Times of Conflicts: CNN's Coverage of the 2003 Iraq War. Mediterranean Journal of Social Sciences, 8 (2), 147-153.

Mhamdi, C. (2017d). Interpreting Games: Meaning Creation in the Context of Temporality and Interactivity. Mediterranean Journal of Social Sciences, 8 (4), 39-46.

Milani, F. (1992). Veils and Words: The Emerging Voices of Iraninan Women Writers. New York: Syracuse University Press.

Sabin, R. (2001). Comics, Comix, and Graphic Novels: A History of Comic Art. London: Phaidon.

Nyberg, A. (1998). Seal of Approval: The History of the Comics Code. Mississippi Jackson: University Press.

Satrapi, M. (2008). Persepolis: The Story of Childhood and the Story of Return. London: Vintage Books.

Sidonie, S and Watsobn, J. (2010). Reading Autobiography: A Guide for Interpreting life Narratives. London: University of Minnesota.

Tabachnick, S.E. (2017). From Comics to the Graphic Novel: William Hogarth to Will Eisner. Cambridge: Cambridge University Press.

Tolmie, J. (2013). Introduction: If a Body Meet a Body. In Drawing from Life: Memory and Subjectivity in Comics Art. (Ed) Tolmie, J: (pp.vii-xxiii). USA: University Press of Mississippi.

Wertham, F. (2003). "Excerpts from the Writings and Speeches of Psychiatrist Frederic Wertham (1895-1981)". Theater, Vol 33 No. 1, pp.18-18. [Accessed 13 September 2018]. Project Muse, muse.jhu.edu/article/41931.

Whitlock, G. (2006). "Autographics: The Seeing 'l' of the Comics". Modern Fiction Studies, 52 (4), 965-979. 